\title{
廃棄物埋立処分場の環境影響評価手法 \\ ENVIRONMENTAL IMPACT ASSESSMENT METHOD \\ FOR A WASTE LANDFILL SITE
}

\author{
井上頼 輝* - 森 沢 真 輔**.小林 一 朗*** \\ By Yoriteru INOUE, Shinsuke MORISAWA and Ichirou KOBAYASHI
}

\section{1.はじめに}

現在，わが国ではアセスメント手法を適用して当該事 業計画の適否が判定されようとしている1). しかしなが ら，アセスメント手法の適用手順が複雑であること，当 該手法によって評価された環境影響の “大きさ”の信頼 度が不明確であること, 環境影響の評価值が評価の主体 （評価する人）によって異なること，等がわざわいして 具体的なアセスメント手法とその適用結果に対しては必 ずしも国民的合意が得られるには至っていない現状であ る.

著者らは都市から発生する一般廃棄物の処理処分事業 を対象にして，同事業によって生ずる環境影響を評価す るための手法について検討した．著者らが検討した評価 手法はネットワーク法の範ちゅうに属しており中村ら ${ }^{2)}$ のいう環境システムマトリックス法に相当する. 中村ら が提案した環境システムマトリックス法は行列を用いる ネットワーク法としては完成度の高い手法であるが，な お以下の諸点について改良の余地を残しているといえ る.すなわち, (1) 評価手法が行列によって構成されて いるにもかかわらず環境影響の評価結果は行列の演算に よっては与えられていない. 中村らは数種類の環境要因 を媒介として発生する環境影響の内最大のものに注目し て, 開発行為による影響を評価する演算手法を採用して いる. それゆえ, この演算手法では複数個の開発行為に より複数個の環境要因を媒介として発生する環境影響の 重畳効果が評価されない, (2) 評価手法を構成する行列 の要素が有次元量であるため要素相互間を直接には比較 することができない. (3) 事業規模の異なる代替案によ る環境影響を評価するためには評価手法を構成する行列

\footnotetext{
* 正会員 工博 京都大学教授 工学部衛生工学教室

** 正会員 工博 京都大学助教授 工学部衛生工学教室

*** 正会員 工修 奈良県浄化センター-
}

をそのつど作り直す必要がある, 等である. 著者らは主 として, (1) 評価手法を構成する行列を単純に行列演算 することにより環境影響の評価值が得られるように行列 の要素を定義することによって演算手法を簡略化すると ともに, 異なる環境要因を媒介とする当該環境影響の重 畳効果が評価できるようにする, (2) 環境要因, 環境影響 の単位変化量の考え方を導人することにより行列の要素 を無次元化し, 要素間の相対的比較を可能にする.さら に, (3) 評価手法を構成する行列に 事業規模を表わす行 列を新たに導入することにより事業規模の異なる計画案 の評価を容易にする，等の改良を試みた。

\section{2. 環境影響評価手法の位置づけ}

環境アセスメントの定義については最近ようやく議論 がまとまりつつあるようであるが, なお, おおかたの合 意を得るには至っていない. 事業計画の実施に伴って生 ずる環境影響 (Environmental Impact) を当該事業の 実施に先だって予測・評価する一連の作業を環境アセス メントとよぶことがあれば, 代替案の評価, 最適計画案 の選定, さらに事業の実施後に行う環境モニタリングま でも環境アセスメントの概念に含ませようとすることも ある. 本研究では, 事業計画の実施に伴って生ずる環 境影響を定量的に予測・評価する作業を環境影響評価 (Environmental Impact Assessment) とよび, さらに 経済性の評価等を加えて最適計画案を選定する一連の作 業を環境アセスメント (Environmental Assessment) と よぶことにする. 本研究で対象にしている環境アセスメ ントの枠組とその作業とを整理して図一1に示す.

図一1 からも理解できるように, 本報で述べる環境ア セスメントでは, 当該事業計画案が棄却されるに至る事 例として 2 例が考えられている. その第一は, 廃棄物埋 立処分場が立地することにより, 史跡・古墳等の歴史的 文化財が破壊されたり，あるいはたとえばコウ，トリ， 
ホタル等の天然記念物の生殖地が奪れたりするよらな, 回復不可能な悪影響が出現する場合である.すなわち， 影響の発生がオール・オア・ナッシングであって, 処分 場の立地場所を変更しない限り影響の発生を予防できな い場合には，環境影響評価を実施する以前の段階ですべ ての計画案を棄却することになる. 第二の例は, 環境影 響評価によって発生すると予測された影響の程度が許容 限度を越えている場合である.この二つの計画案無条件
裹却の判断基準をま妨れた計画案のみが最適案選定の 段階（総合評価の段階）に送られることになる.

\section{2. 環境影響の評価手法}

\section{（1）開発行為亡環境影響}

本報では, 当該事業計画の実施に伴って生ずる環境影
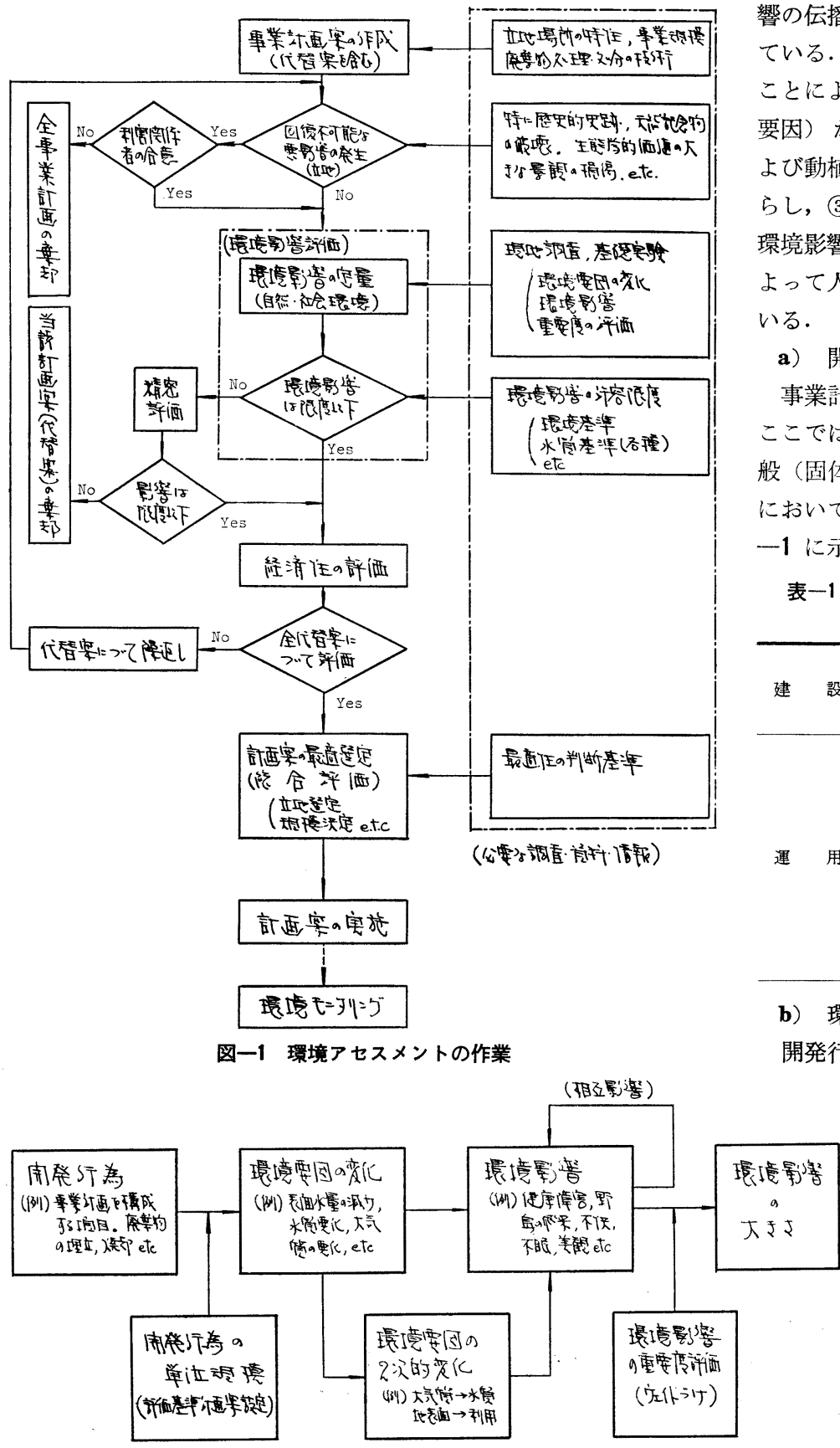

図一2 想定した環境の構造（環境影響の伝播とその評価経路）
響の伝播経路が図一2のようであると想定し ている、すなわち，(1) 事業計画を実施する ことによって, 環境を構成する諸要因（環境 要因）が変化し，(2) 環境要因の変化が人お よび動植物に種々の影響 (環境影響) をもた らし，(3) その影響を人が主観的に評価して， 環境影響の大きさを定量する，一連の過程に よって人の生活環境に悪影響が及ぶと考えて いる.

\section{a) 開発行為}

事業計画を構成する具体的な作業項目を, ここでは開発行為とよぶ. 都市で発生する一 般 (固体) 廃棄物を処理し処分する事業計画 において考えられる開発行為を整理して表 -1 に示す.

\section{表-1 廃萐物の処理・処分事業を構成する} 開発行為のリスト

\begin{tabular}{|c|c|c|c|}
\hline 建 & 設 & $\begin{array}{l}1 \\
2 \\
3\end{array}$ & $\begin{array}{l}\text { 処理・管理用施設等の構造物 } \\
\text { 専用道路・橋等 } \\
\text { 廃集物埋立用構造物 }\end{array}$ \\
\hline 運 & 用 & $\begin{array}{c}4 \\
5 \\
6 \\
7 \\
8 \\
9 \\
10 \\
11 \\
12\end{array}$ & $\begin{array}{l}\text { 廃棄物の焼却 } \\
\text { 大気污染防止設備の運用 } \\
\text { 焼却用施設廃水の処理 } \\
\text { 焼却灰の埋立処分 } \\
\text { 非焼却廃菓物の埋立処分 } \\
\text { 埋立場漫出水の処理 } \\
\text { 埋立用ブル・ドーザの稼動 } \\
\text { トラックによる廃裹物の輸送 } \\
\text { 埋立場の衛生管理 }\end{array}$ \\
\hline
\end{tabular}

b) 環境要因

開発行為によって変化する 環境の構成要 素, 開発行為の実施によって波及 的に誘発される社会現象等で, 次 に述べる環境影響になんらかの変 化をもたらす因子をここでは環境 要因とよぶ. 廃棄物の焼却・埋立 処分事業において考虑すべきと思 われる環境要因を整理して 表一2 に示す.

\section{c) 環 境影響}

事業計画の実施によって生ずる 種々の影響を評価するために選定 
表一2 環境要因のリスト

\begin{tabular}{|c|c|c|c|c|c|c|c|}
\hline 永用 & 永 & 1 & 表面水の水量 & \multirow{6}{*}{$\begin{array}{l}\text { 大 } \\
\text { 気 } \\
\text { 污 } \\
\text { 染 }\end{array}$} & \multirow{2}{*}{ 気 } & \multirow[t]{3}{*}{12} & 窒素酸化物 \\
\hline \multirow{5}{*}{$\begin{array}{l}\text { 水 } \\
\text { 質 }\end{array}$} & \multirow{6}{*}{ 面 } & 2 & BOD & & & & \multirow{4}{*}{$\begin{array}{l}\text { 塩化水素ガス } \\
\text { 炭化水素ガス } \\
\text { 一酸化炭素ガス }\end{array}$} \\
\hline & & 3 & カドミウム濃度 & & \multirow[b]{2}{*}{ 体 } & & \\
\hline & & 4 & 六価クロム濃度 & & & $\begin{array}{l}15 \\
16\end{array}$ & \\
\hline & & 5 & 鉛蕽度 & & & & \\
\hline & & 6 & 銅 濃 度 & & 物下 & 17 & 楳 \\
\hline \multirow{4}{*}{$\begin{array}{l}l^{\prime j} \\
\text { 濁 }\end{array}$} & & 7 & 垔 鉛 漲 度 & & 奥 & 18 & 悪 \\
\hline & 地 & 8 & BOD & & & & \\
\hline & 下 & 9 & 塩素イオン潧度 & 土利 & 諘 & 19 & 地表面の形態 \\
\hline & 水 & 10 & 重金属濃度 & 地用 & 面 & 20 & 地表面の性状 \\
\hline 音 & 騒 & 11 & 騒 & 絁他 & 䢒 & 21 & 交 通 現 象 \\
\hline
\end{tabular}

表一3環境影響のリスト

\begin{tabular}{|c|c|c|c|}
\hline \multirow{3}{*}{$\begin{array}{l}\text { 生活環境 } \\
\text { の影䍌 }\end{array}$} & 陸上植物 & $\begin{array}{l}1 \\
2 \\
3\end{array}$ & $\begin{array}{l}\text { 農作物・草花等の成長阻害 } \\
\text { 農作物への有害物質の蓄積 } \\
\text { 自然植生の変化 }\end{array}$ \\
\hline & 陸上動物 & $\begin{array}{l}4 \\
5 \\
6 \\
7\end{array}$ & $\begin{array}{l}\text { 野鳥等の野生動物 } \\
\text { スズメ等の害鳥の飛来 } \\
\text { ハエ・蚊の発生 } \\
\text { 家畜 (ニワトリ・豚等) }\end{array}$ \\
\hline & 魚 & 8 & 魚類 \\
\hline \multirow{2}{*}{$\begin{array}{l}\text { 身体的 } \\
\text { 影䉕 }\end{array}$} & 直接障害 & $\begin{array}{c}9 \\
10 \\
11 \\
\end{array}$ & $\begin{array}{l}\text { 経口掑取による健康障害 } \\
\text { 大気污染による健康障害 } \\
\text { 光化学スモック等による急性障害 }\end{array}$ \\
\hline & 間接障害 & $\begin{array}{l}12 \\
13 \\
\end{array}$ & $\begin{array}{l}\text { 睡眠阻害・不眠 } \\
\text { 精神阻害（不快） }\end{array}$ \\
\hline \multicolumn{2}{|c|}{ 社会的影響 } & $\begin{array}{l}14 \\
15 \\
16 \\
17\end{array}$ & $\begin{array}{l}\text { レクレーション活動の阻害 } \\
\text { 美観の変化 } \\
\text { 土地利用の制約 } \\
\text { 交通事故の増加 }\end{array}$ \\
\hline
\end{tabular}

する項目である．人（個人および集団）の生命や健康, あるいは快適な生活をおびやかす種々の事象のうち, 直 接にそれらと関わるものを選定する．環境影響の選定例 を整理して表一3に示す.

\section{（2）環境影響評価の数理手法}

a) 評価手法の数学的背景

図一2で想定した 環境影響の 発生・伝播経路に 沿っ て, 当該影響を評価する数理モデルを構成する.

当該事業計画を構成する $n$ 個の開発行為を列ベクトル $\boldsymbol{x} \equiv\left(x_{1}, x_{2}, \cdots, x_{n}\right)^{T}$ で, 環境を構成する $m$ 個の環境 要因を同じく列べクトル $\boldsymbol{e} \equiv\left(e_{1}, e_{2}, \cdots, e_{m}\right)^{T}$ で表示す る. 任意の環境要因 $e_{m}(1 \leqq m \leqq m)$ が $n$ 個の開発行 為の線形結合で記述できるものとする.すなわち，

$$
\begin{gathered}
e_{m}=p_{m, 1} x_{1}+p_{m, 2} x_{2}+\cdots+p_{m, n} x_{n} \cdots \cdots \cdots(1) \\
(m=1,2, \cdots, m)
\end{gathered}
$$

上式を行列を用いて書き改めると，次式を得る.

$$
\boldsymbol{e}=\boldsymbol{P} \cdot \boldsymbol{x} \text {. }
$$

行列 $\boldsymbol{P}$ の構成については後述する図一4 を参照され たい.

ついで, 環境要因が変化することによって生ずる環境
影響を評価する関係式を定める，ここでは，評価すべき 環境影響が $l$ 個あり, 任意の環境影響 $f_{l}(1 \leqq l \leqq l)$ が $m$ 個の環境要因の 線形結合で記述できるものとする. すなわち,

$$
\begin{array}{r}
f_{l}=q_{l, 1} e_{1}+q_{l, 2} e_{2}+\cdots+q_{l, m} e_{m} \\
(l=1,2, \cdots, l)
\end{array}
$$

一方, $m$ 個の環境要因のらちには, たとえば大気中 に浮遊する媒塵のようにそれが降下することによって二 次的に他の環境要因, たとえば河川や湖沼の水質, を変 化させるものがある. この環境要因の二次的変化の大き さは, たとえば廃棄物处理処分場の浸出液の処理水を放 流することによって生ずる河川水質（環境要因）の変化 （一次変化）の大きさに比べると小さい， $m$ 個の環境要 因のうち, 他の環境要因の変化に伴って生ずる二次的変 化を評価する必要がある環境要因の数を $k$ 個 $(1 \leqq k<$ $m)$ とし, その環境要因を $f_{l+k}$ で表示する. すなわち, $f_{l+k}$ は $k$ 個の環境要因のうちのいずれかを表わすこと になる. $f_{l+k}$ もまた, $m$ 個の環境要因の線形結合で与 えられるとすると, 次の関係式を得ることができる.

$$
\begin{gathered}
f_{l+k}=q_{l+k, 1} e_{1}+q_{l+k, 2} e_{2}+\cdots+q_{l+k, m} e_{m} \cdots(4) \\
(l=l: k=1,2, \cdots, k)
\end{gathered}
$$

$l$ 個の環境影響と, $k$ 個の二次的に変化する環境要因 とをあわせて, 列べクトル $\boldsymbol{f}=\left(f_{1}, f_{2}, \cdots, f_{l}, f_{l+1}\right.$, $\left.f_{l+2}, \cdots, f_{l+k}\right)^{T}$ で表示する. このとき式 (3), (4) は次 のように行列を用いて書き改めることができる.

$$
\boldsymbol{f}=\boldsymbol{Q} \cdot \boldsymbol{e}
$$

行列 $\boldsymbol{Q}$ の構成については後述する図一6 参照され たい.

ついで，環境影響間の相互影響を評価する関係式を定 める. 環境影響間のすべてに相互作用があるとは限らな い.しかしながら，たとえば環境影響の1つとして「農 作物への有害物質の蓄積」（米に $\mathrm{Cd}$ が蓄積すると商品 価值が下落する) をとると, 農作物に有害物質が蓄積す ることにより農産物の商品価值が下落するだけでなく, その農作物を摂取することにより他の環境影響「経口摄 取による健康障害」にも影響が及ぶ. 環境影響の変化経 路は 図一2 よりわかるように, (環境要因の変化) $\rightarrow$ (環 境影響) $\rightarrow$ (環境影響間の相互作用) だけでなく，(環境 要因の変化) $\rightarrow$ (環境要因の二次的変化 $) \rightarrow$ (環境影響) $の$ 経路もある. 後者の経路について影響間の相互作用を考 慮しないのは, すでに述べたように環境要因の二次的変 化の大きさが一次的変化の大きさに比較して小さく, そ れゆえ, それに伴って生ずる環境影響の大きさも前者の 経路によって生ずる環境影響の大きさに比べて相対的に 小さいと考えられるからである.

相互影響と環境要因の二次的変化による影響とを考慮 した環境影響 $z_{j}$ が, 環境影響 $f_{j}(1 \leqq j \leqq l)$ と二次 
的環境要因変化 $f_{l+k}(1 \leqq k \leqq k)$ との線形結合で記述 できるものとする．このとき，次の関倸式が得られる.

$$
\begin{gathered}
z_{j}=r_{j, 1} f_{1}+r_{j, 2} f_{2}+\cdots+r_{j, l} f_{l} \\
+r_{j, l+1} f_{l+1}+\cdots+r_{j, l+k} f_{l+k} \\
(j=1,2, \cdots, l)
\end{gathered}
$$

$l$ 個の環境影響を列ベクトル $z \equiv\left(z_{1}, z_{2}, \cdots, z_{l}\right)^{T}$ で 表わすと式 (6) は行列を用いて次式のように書き改める ことができる.

$$
z=R \cdot f
$$

行列 $\boldsymbol{R}$ の構成については後述する図一8 を参照され たい，環境影響ベクトル $\boldsymbol{z}$ は，自然科学的尺度を用い て定量的に評価することが比較的容易なベクトルである といえる.

自然科学的尺度を用いて定量された環境影響あるいは 当該事業計画の 実施によって生ずる 環境影響の 増加分 (上乗せ分) の大きさは, 客観的には, ある程度べクト ル $\boldsymbol{z}$ によって評価することができる.しかしながら， 環境影響を受ける個人または集団の活動範囲, 廃棄物埋 立処分場からの距離, 処分場の操業後経過時間, あるい は当該個人または集団が異なる事業の実施によって現に 受けている環境影響の大きさ, 等によって, 自然科学的 尺度で表現した環境影響の大きさは同じであっても，影 響の効果やその主観的評価は異なる.ここでは, このよ うな環境影響を受ける側の諸条件に基づいて, 個々の環 境影響に相対的重みを配することにする. 当該環境影響 $z_{l}$ に重要度を評価して得られる環境影響を $y_{l}$ とする と, 両者の間には,

$$
y_{l}=w_{l, l} z_{l} \quad(l=1,2, \cdots, l)
$$

なる関倸式が成立する.ここに, $w_{l, l}$ は第 $l$ 番目の環 境影響の相対的重要度である. $l$ 個の環境影響 $y$ を列へ クトル $\boldsymbol{y} \equiv\left(y_{1}, y_{2}, \cdots, y_{l}\right)^{T}$ で表示すると, 式（8）は 行列を用いて次式のように書き改めることができる.

$$
\left(\begin{array}{c}
y_{1} \\
y_{2} \\
\vdots \\
y_{l}
\end{array}\right)=\left(\begin{array}{ccc}
w_{1,1} & & \\
& w_{2,2} & 0 \\
0 & \ddots & \\
0 & & w_{l, l}
\end{array}\right)\left(\begin{array}{c}
z_{1} \\
z_{2} \\
\vdots \\
z_{l}
\end{array}\right) .
$$

あるいは,

$$
\boldsymbol{y}=\boldsymbol{W} \cdot \boldsymbol{z}
$$

式 (2)，(5),(7)，(10) を順次代入することにより次式 を得ることができる.

$$
\begin{aligned}
& z=\boldsymbol{R} \cdot \boldsymbol{Q} \cdot \boldsymbol{P} \cdot \boldsymbol{x} \cdots \\
& \boldsymbol{y}=\boldsymbol{W} \cdot \boldsymbol{R} \cdot \boldsymbol{Q} \cdot \boldsymbol{P} \cdot \boldsymbol{x}
\end{aligned}
$$

式（11）は当該事業計画によって生ずる環境影響を自 然科学的尺度で表わす評価式であり, 式 (12) は, さら に影響を受ける側の諸条件を考慮した環境影響の評価式 である.

上で定義した 4 つの行列, $\boldsymbol{P}, \boldsymbol{Q}, \boldsymbol{R}, \boldsymbol{W}$ の要素 $p_{m, n}$, $q_{l, m}, r_{l, l}, w_{l, l}$ はおのおの環境要因の変化原単位, 環境
影響の変化原単位あるいは増幅係数のような性質を有す る.同じ行列の要素であっても, 行と列とが異なれば単 位（次元）も異なる. それゆえ, 行列要素のおのおのは そのままでは相互比較の対象にならない。ここでは, 各 行列要素を無次元化して, 当該行列要素の值が相対的な 意味をもつようにする.

式 (2) で定義される行列 $\boldsymbol{P}$ を模式的に $\left(e_{m} / x_{n}\right)$ で表 わす. 式 (11) の他の行列についても同様な模式的表示 を採用する.このとき式 (12) は模式的に次のように書 くことができる.

$$
\left(y_{i}\right)=\left(\frac{y_{i}}{z_{l}}\right) \cdot\left(\frac{z_{l}}{f_{l}}\right) \cdot\left(\frac{f_{l}}{e_{m}}\right) \cdot\left(\frac{e_{m}}{x_{n}}\right) \cdot\left(x_{n}\right) \cdots
$$

開発行為 $x_{n}$, 環境要因 $e_{m}$, 環境影響 $f_{l}$ と $z_{l}$ に, おのおの単位 (変化) 量を与えて, それらを $\hat{x}_{n}, \hat{e}_{m}$, $\hat{f}_{l}, \hat{z}_{l}$ で表わす. $\hat{x}_{n}, \hat{e}_{m}, \hat{f}_{l}, \hat{z}_{l}$ を用いて式 (13) を次 のように変形する.

$$
\begin{aligned}
\left(y_{i}\right)= & \left(\frac{y_{i}}{z_{l} / \hat{z}_{l}}\right) \cdot\left(\frac{z_{l} / \hat{z}_{l}}{f_{l} / \hat{f}_{l}}\right) \cdot\left(\frac{f_{l} / \hat{f}_{l}}{e_{m} / \hat{e}_{m}}\right) \\
& \cdot\left(\frac{e_{m} / \hat{e}_{m}}{x_{n} / \hat{x}_{n}}\right) \cdot\left(\frac{x_{n}}{\hat{x}_{n}}\right) \ldots \ldots \ldots \ldots \ldots
\end{aligned}
$$

式 (14) は開発行為, 環境要因, 環境影響をおのおの 対応する単位（変化）量を尺度にして測り直すことを意 味する.ここで, 式 (14) の右辺，（）でくくられた部 分を，それぞれ対応する行列で置き戻す.すなわち，

$$
\left(\begin{array}{ll}
\boldsymbol{P} \equiv\left(\frac{e_{m} / \hat{e}_{m}}{x_{n} / \hat{x}_{n}}\right), & \boldsymbol{Q} \equiv\left(\frac{f_{l} / \hat{f}_{l}}{e_{m} / \hat{e}_{m}}\right) \\
\boldsymbol{R} \equiv\left(\frac{z_{l} / \hat{z}_{l}}{f_{l} / \hat{f}_{l}}\right), & \boldsymbol{W} \equiv\left(\frac{y_{i}}{z_{l} / \hat{z}_{l}}\right)
\end{array}\right.
$$

すでに明らかなように, 式 (15) で再定義した行列 $\boldsymbol{P}$, $\boldsymbol{Q}, \boldsymbol{R}, \boldsymbol{W}$ は，それぞれ式 (2),(5)，(7)，(10) で定義さ れた行列 $\boldsymbol{P}, \boldsymbol{Q}, \boldsymbol{R}, \boldsymbol{W}$ とは少し性質が変わっている. すなわち, 式 (2), (5), (7),(10) で定義される行列の要 素は有次元数であるのに対し, 式 (15) で定義される行 列の要素は, 行列 $\boldsymbol{W}$ を除き, 無次元数である. 式 (14) 中 $\left(x_{n} / \hat{x}_{n}\right)$ に対応する, 要素数 $n$ の列ベクトルを $\boldsymbol{m}$, すなわち,

$$
\boldsymbol{m} \equiv\left(x_{n} / \hat{x}_{n}\right)
$$

とし, $\boldsymbol{m}$ を次式のように行列 $M$ とベクトル $\boldsymbol{i}$ の積に分 解する.

$$
\boldsymbol{m}=\boldsymbol{M} \cdot \boldsymbol{i}
$$

$\boldsymbol{M}$ は $n$ 行 $n$ 列の対角行列であり, $\boldsymbol{i}$ は要素数 $n$ の 列ベクトルである.ここで, 行列 $\boldsymbol{M}$ の対角要素 $m_{n}$ に は, 対応する開発行為の規模（大きさ）を, 単位開発規 模を尺度にして測定した量, 寸なわち, $x_{n} / \hat{x}_{n}$ の值（無 次元）を，また， $i$ の要素（有次元）にはすべて，常に 值 1.0 を与えることにする.このように列ベクトル $\boldsymbol{i}$ を 設定しても一般性を損なうことはない。

式 (15),(17)を用いて, 式 (14) を書き改めると, 式 
(12）に相当する式として，

$$
\boldsymbol{y}=\boldsymbol{W} \cdot \boldsymbol{R} \cdot \boldsymbol{Q} \cdot \boldsymbol{P} \cdot \boldsymbol{M} \cdot \boldsymbol{i}
$$

を得る，一方，式 (11) に相当する式としては， $z / \hat{z}=\boldsymbol{R} \cdot \boldsymbol{Q} \cdot \boldsymbol{P} \cdot \boldsymbol{M} \cdot \boldsymbol{i}$

を得る. 式 (19) の左辺 $\boldsymbol{z} / \hat{\boldsymbol{z}}$ は, 環境影響 $z_{l}$ をおの おの対応する単位量 $\hat{z}_{l}$ で正規化してできる（各要素が 無次元数の）要素数 $l$ の列ベクトルである. 式 (18), （19）の計算では，数学的な行列演算を実施すればよい ことになる。

b) 単位 (開発) 規模, 単位変化量の設定

各開発行為の 規模を 無次元化するために用いる 単位 （開発）規模は任意に設定することができる. 当該事業 計画の実施に伴って生じる環境影響は基準になる事業計 画によって生じる環境影響と比較されることになる．た とえば, 基準事業計画として現行の廃棄物処理処分事業 を採用すれば新しく計画する処理処分事業による環境影 響が現在の環境影響と比較されることになる. 廃棄物処 理処分事業の場合には, ほとんどの場合既存の事業が進 行中であるからその事業の規模を単位規模に設定すれば よい. 開発行為の規模 (有次元量)を単位規模(有次元量) で除して得られる無次元量をここでは規模指数とよぶこ とにする。

環境影響および環境要因の単位変化量も任意に設定す ることができる．ここでは以下のように設定する.すな わち, 環境影響の許容限度をその環境影響の単位変化量 とし, 許容限度の環境影響を生じる環境要因の変化量を その環境要因の単位変化量とする. 環境影響の許容限 度としては, たとえば環境基準值, 飲料水基準值, 農業 用水基準值, なんらかの身体的・情緒的悪影響が顕在化 する限度值等を用いることにする．環境影響および環境 要因の変化量 (有次元量) をそれぞれ対応する単位変化 量 (有次元量) で除して得られる無次元量をここでは変 化指数とよぶことにする. 上記のように単位変化量を設 定するとすべての環境影響をおのおの対応する許容限度 に相対的に計量することができるため，事業計画の棄却 基準を統一的に記述できる（式 (30) 参照), 異なる環境 影響の程度を相対的に比較できるようになる，等の利点 を得ることができる。

c）「開発行為一環境要因」マトリックス $(\boldsymbol{P})$

開発行為と環境要因の変化との関係を記述する行列で ある. 式 (15) より, 行列 $\boldsymbol{P}$ の要素 $p_{m, n}$ の性質は次 式で定まる。

$$
\begin{aligned}
& \text { (第 } m \text { 環境要因の変化量) / } \\
& p_{m, n}=\frac{\text { (第 } m \text { 環境要因の単位変化量) }}{\text { (第 } n \text { 開登行為の規模)/ }} \\
& \text { (第 } n \text { 開発行為の単位規模) } \\
& \llcorner\text { (第 } m \text { 環境要因の変化指数) } \\
& \text { (第 } n \text { 開発行為の規模指数) }
\end{aligned}
$$

つまり, $p_{m, n}$ の值を定めるためには，まず，(1) 第 $m$
環境要因と第 $n$ 開発行為の規模との関係をグラフに示 し，(2) 環境要因軸，開発行為規模軸をおのおの対応す る単位変化量, 単位規模を用いて縮尺し, (3) 得られた グラフ (図一3) の当該開発規模の位置での勾配を算出し て, (4) $p_{m, n}$ の值とすればよい.ここでは簡単のため開 発行為の規模と環境要因の変化とが線形関係にあるもの とする.この場合には, 図一3より明らかなように, グ ラフの勾配あるいは開発行為の規模指数が 1.0 のときの 環境要因の変化指数が $p_{m, n}$ の值として採用されること になる．つまり， $p_{m, n}$ 第 $n$ 開発行為が単位規模であ る場合の第 $m$ 環境要因の変化指数に等しい. このよう にして定めた $p_{m, n}$ を要素とする行列 $\boldsymbol{P}$ は, 当該事業 計画の実施場所が変わらない限り不変である.

行列 $\boldsymbol{P}$ の行方向には原因となる $n$ 個の開発行為が, また, 列方向には結果となる $m$ 個の環境要因が配置さ れる(図-4 参照).

d）「環境要因一環境影響」マトリックス $(\boldsymbol{Q})$

環境要因の変化と環境影響との関係を記述する行列で あるが，すでに述べたように環境要因の変化と環境要因 の 2 次的変化と関係を記述する部分行列を含んでいる. 式(15)より行列 $\boldsymbol{Q}$ の要素 $q_{l, m}$ の性質は次式で定まる. $q_{j, m}=\left\{\begin{array}{l}\frac{(\text { 第 } j \text { 環境影響の変化指数 })}{(\text { 第 } m \text { 環境要因の変化指数 })}(1 \leqq j \leqq l) \\ \frac{(2 \text { 次的に変化する環境要因の変化指数 })}{(\text { 第 } m \text { 環境要因の変化指数 })}\end{array}\right.$ $\cdots \cdots(l+1 \leqq j \leqq l+k) \cdot$

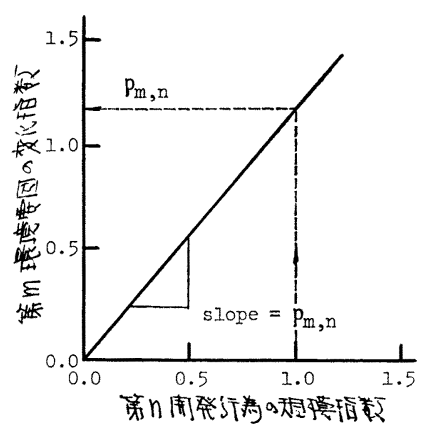

図一3 行列要素 $\boldsymbol{p}_{m, n}$ の決定方法

（指数は変化量を単位量で除して得る）

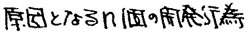

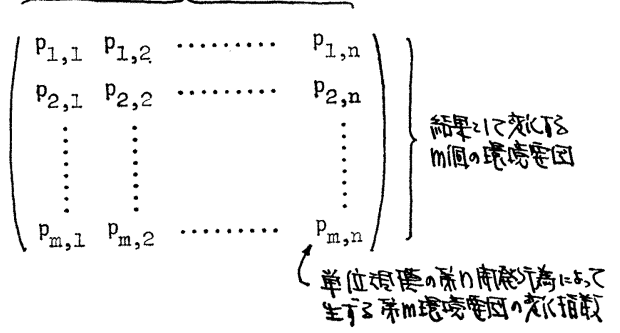

図一4 P マトリックスの構成 


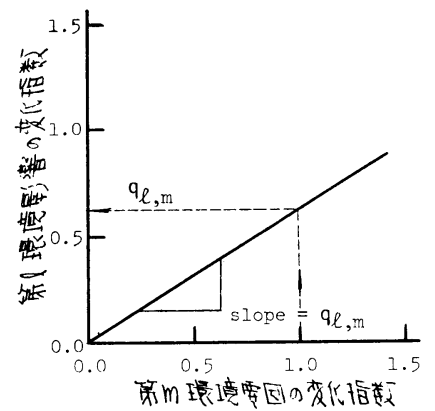

図一5 行列要素 $\boldsymbol{q}_{l, m}$ の決定方法 (変化指数 $)=($ 変化量 $) /($ 単位変化量 $)$

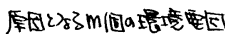

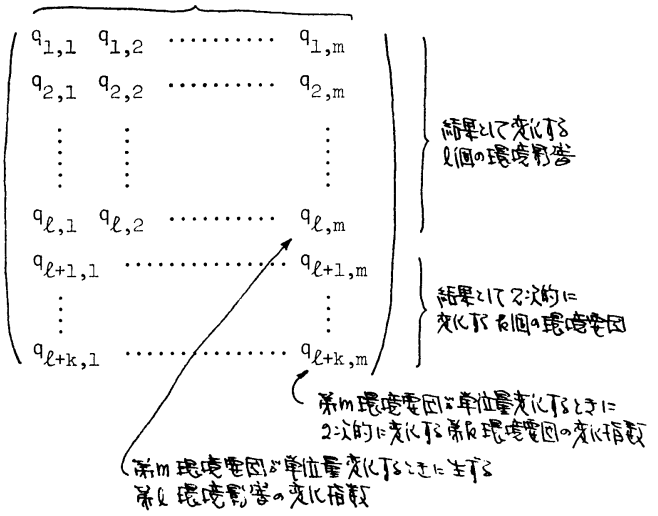

図一6 $Q$ マトリックスの構成

ただし，環境影響の変化指数は，環境影響の変化量を 単位変化量で除して与えられるものとする. 図一5 に示 すように環境要因（の変化指数）と環境影響（の変化指 数）とが，評価対象の範囲内で 線形関係にある場合に は, $q_{l, m}$ は両者の関係を示寸直線の勾配で与えられる. 環境要因の 2 次的変化を評価する場合もまったく同じ手 続きを適用できる.このようにして定めた要素 $q_{l, m}$ で 構成される行列 $\boldsymbol{Q}$ は, 当該事業計画が実施される場所 が変わらない限り不変である.

図一1において示したように，環境影響が許容される 限度以上になる, たとえば河川水中のカドミウム濃度が 環境基準值以上になったり，玄米中のカドミウム濃度が
行列 $\boldsymbol{Q}$ の構成を 図一6 に示す. 行列 $\boldsymbol{Q}$ の行方向に は，原因となる $m$ 個の環境要因が，また，列方向には 結果として変化する $l$ 個の環境影響と $k$ 個の環境要因 が配置される。

e）「環境影響一環境影響」マトリックス $(\boldsymbol{R})$

主として 環境影響間の 相互作用を 記述する 行列であ る.ただし，2次的に変化する環境要因と環境影響との 関係を記述する部分行列を含む. 式 (15) より, 行列 $\boldsymbol{R}$ の要素 $r_{l, j}$ の性質は次式で定まる.

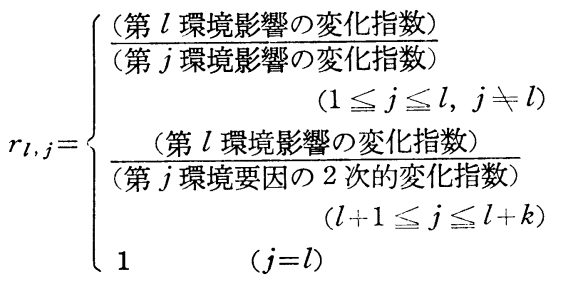

第 $l$ 環境影響と第 $j$ 環境影響との関倸が線形である と寸れば， $r_{l, j}$ は 図一7 より明らかなように，やはり 両者の関係を示寸直線の勾配として定められる. 2 次的 に変化した環境要因と環境影響との関係を記述する要素 $r_{l, j}(l+1 \leqq j \leqq l+k) \quad$ も同様にして定めることができ る.このようにして定められた要素 $r_{l, j}$ で構成される 行列 $\boldsymbol{R}$ は, 当該事業計画が実施される場所が変わらな い限り不変である。

行列 $\boldsymbol{R}$ の構成を図一8 に示寸.

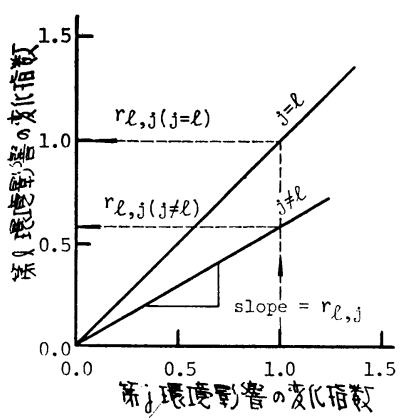

図-7 行列要素 $\boldsymbol{r}_{l, j}$ の決定方法

(変化指数 $)=($ 変化量 $) /($ 単位変化量 $)$ ある限度以上になり商品価值を失うようになる場 合には，当該計画案は菓却されることになる，そ れゆえ，環境影響を評価する場合の環境要因の変 動域は，実質的には，たとえば環境基準值以下の 領域に限られる.この領域での要因と影響との関 係は，現在，生理学的に必ずしも解明されている とはいいにくい。したがって，両者の間に線形仮 定を導入することによって生ずる誤差は安全側に 現われるものと期待される. 要因と影響との関係 にしきい值がある場合には，誤差は明らかに安全 側に現われる.

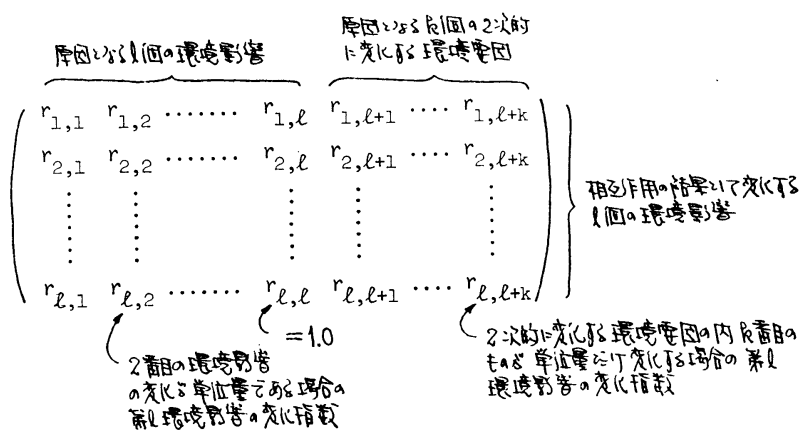

図一8 $R$ マトリックスの構成 
f) 重要度マトリックス $(\boldsymbol{W})$

行列 $W$ : $l$ 行 $l$ 列の対角行列である. 行列 $\boldsymbol{W}$ の 第 $j$ 番目の対角要素 $w_{j, j}$ の性質は式 (15) より次の ように定まる。

$$
w_{j, j}=\frac{(\text { 第 } j \text { 環境影響の相対的重要度) }}{(\text { 第 } j \text { 環境影響の変化指数 })}
$$

$w_{j, j}$ は，環境影響を被る個人あるいは集団が，当該 環境影響を他の環境影響に比べて相対的にどの程度より 重要であると考えるかによって定まる．相対的重要度を 評価する手法としては，たとえば対象になる個人または 集団に対してアンケート調查を実施し，重要度の大きい 順に環境影響に番号をつける方法がある.このような方 法によって相対的重要度を評価すると, その重要度は, 通常は, 個人または集団が現に受けている環境影響の水 準において判断された值をとることになる. 事業計画の 実施によってもたらされる環境影響水準に抢いて与えら れる相対的重要度を得ることが望ましいが，それは不可 能な場合が多い.しかも, そのようにして定めた重要度 は，個々の環境影響水準の関数になる.ここでは, 各環境 影響の変化がすべて単位量である場合について定められ た相対的重要度を用いて行列 $\boldsymbol{W}$ を決定することにする。 このようにして定めた $w_{j, j}$ を要素とする行列 $\boldsymbol{W}$ は, 対象とする個人または集団が変わらない限り不変であ る.

g) 開発規模マトリックス $(\boldsymbol{M})$

式（17）で定義したように, 行列 $\boldsymbol{M}$ は $n$ 行 $n$ 列の 対角行列である. $\boldsymbol{M}$ の第 $j$ 番目の対角要素 $m_{j, j}$ は次 式で定めら礼る.

$$
m_{j, j}=\frac{\text { (第 } j \text { 開発行為の規模 })}{(\text { 第 } j \text { 開発行為の単位規模 })}
$$

すなわち, $m_{j, j}$ は第 $j$ 開発行為の規模指数である. 事業計画の規模を全体に大きくしたり，あるいは事業計 画の質を変更する（たとえば，収集する廃棄物のうち焼 却処理をする比率を増加させる）等の代替案を考慮する 場合には $\boldsymbol{M}$ マトリックスの対角要素 $m_{j, j}$ の値を変更 させればよい，事業部画の規模を 2 倍にする場合には $m_{j, j}$ をすべて 2 倍にし，廃棄物の焼却比率を $50 \%$ か ら $80 \%$ に増加させ，焼却せずに埋立する比率を $50 \%$ か ら $20 \%$ に減少させる場合には, 廃棄物焼却の $m_{j, j}$ を 1.6 倍に, 非焼却埋立の $m_{j, j}$ を0.4 倍にすることにな る. 行列 $\boldsymbol{M}$ は事業計画を構成する開発行為の数とその 規模（指数）によってのみ定まる.

h）環境影響マトリックス $(\boldsymbol{B})$

$$
\text { 式 (19) に扎い, }
$$

$$
\boldsymbol{B} \equiv \boldsymbol{R} \cdot \boldsymbol{Q} \cdot \boldsymbol{P} \cdot \boldsymbol{M}
$$

とおくと, 式 (19) は次式のように書き改めることがで きる. B を環境影響マトリックスとよぶ.

$$
\boldsymbol{z} / \hat{z}=\boldsymbol{B} \cdot \boldsymbol{i}
$$

行列 $\boldsymbol{B}$ は $l$ 行 $n$ 列の行列になる. $\boldsymbol{B}$ の要素を $b_{j, n}$ で記述して, 式 (26) を代数式で書き改めると次式を得 る. すでに述べたように, 列ベクトル $i$ の $n$ 個の要素 の值は常に 1.0 に設定していることに留意する必要が ある。

$$
z_{j} / \hat{z}_{j}=\sum_{n=1}^{n} b_{j, n}(j=1,2, \cdots, l)
$$

上式の左辺法重要度を評価しない環境影響 $z_{j}$ の変化 指数である.すなわち, 式 (27) は第 $j$ 環境影響の変 化指数が, 行列 $\boldsymbol{B}$ の第 $j$ 行要素 $n$ 個の単純和で与え られることを示している. つまり, 行列 $\boldsymbol{B}$ の要素 $b_{j, n}$ は第 $n$ 番目の開発行為によって生じる第 $j$ 番目の環境 影響の変化指数を表わしている. それゆえ, $n$ 個の開発 行為（当該事業計画の実施）によって生じる第 $j$ 環境影 響の変化指数は, $b_{j, n}$ を開発行為 $n$ について加算する ことにより与えられることになる.

$b_{j, n}$ のこのような性質は, 行列 $\boldsymbol{R}, \boldsymbol{Q}, \boldsymbol{P}, \boldsymbol{M}$ の各要 素の性質と $\boldsymbol{B}$ の定義式 (25) とから次のように明らか にすることができる. 行列 $\boldsymbol{R}, \boldsymbol{Q}, \boldsymbol{P}$ の要素はそれぞれ 原因事象（環境要因または環境影響）と結果事象（環境 要因または環境影響）とが作る線形グラフの勾配で与え られた.つまり, 各要素は数值的には原因事象の変化指 数が 1.0 (変化量が単位変化量に等しい) の場合の結果 事象の変化指数に等しい.ゆえに式（25）より,

$$
\begin{aligned}
& b_{j, n}=\sum_{k, m, n} r_{j, k} \cdot q_{k, m} \cdot p_{m, n} \cdot m_{n, n} \cdots \cdots \cdots \cdots(28) \\
& =\Sigma\left(\begin{array}{c}
\text { 第 } k \text { 環境影響の変化が単位量の } \\
\text { きの第 } j \text { 環境影の変化数 }
\end{array}\right) \\
& \text { 、(第 } m \text { 環境要因の変化が単位量の }) \\
& \text { (ときの第 } k \text { 環境影響の変化指数 } \\
& \times\left\{\left(\begin{array}{l}
\text { 第 } n \text { 開発行為が巣位規模の } \\
\text { きの第 } m \text { 環境要因の指数 }
\end{array}\right)\right. \\
& \text { 、(第 } n \text { 開発行為の規模指数) }\} \\
& =\Sigma\left(\begin{array}{c}
\text { 第 } k \text { 環境影響の变化が単位量の } \\
\text { ¿の第 } k \text { 環境影響の変化指数 }
\end{array}\right) \\
& \text { 、(第 } m \text { 環境要因の孪化が単位量の } \\
& \left(\begin{array}{l}
\text { 第 } n \text { 開発行為が当該計画規模のと } \\
\text { きの第 } m \text { 璄境要因の変化指数 }
\end{array}\right)
\end{aligned}
$$

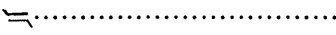

$$
\begin{aligned}
& =\Sigma\left(\begin{array}{c}
\text { 第 } n \text { 開發行為が当該計画規模の } \\
\text { ¿きの第 } j \text { 環境影響の変化指数 }
\end{array}\right)
\end{aligned}
$$

となる. すなわち, 行列 $\boldsymbol{B}$ の要素 $b_{j, n}$ は先にも述べ たように, 第 $n$ 番目の開発行為が種々の環境要因, 環境 影響を媒介として引き起こす第 $j$ 環境影響の変化指数を 示す. 式 (27) に対応して, 行列 $\boldsymbol{B}$ の列要素の単純和 $\sum_{j=1}^{l} b_{j, n}(n=1,2, \cdots, n)$ を計算すると, それは $n$ 番目 の開発行為のみが原因となって生ずる環境影響の大きさ 
（ $l$ 個の環境影響の変化指数の総和）を与える.

行列 $\boldsymbol{B}$ の各要素をそれぞれ列方向, 行方向に加算す る演算は, 各要素が単位変化量, 単位規模を用いて処理 された無次元数であるため数学的にも問題がない. 行列 $\boldsymbol{B}$ の要素 $b_{j, n}$ は相対的な比較に耐える量である.たと えば,

$$
b_{10,4}=0.8>b_{2,8}=0.4
$$

であったとする. 表一 1 より $n=4$ の開発行為は「ごみ の焼却」, $n=8$ は「廃棄物の埋立処分」, 一方, 表一3 より $j=2$ の環境影響は「農産物への有害物質の蓄積」, $j=10$ は「大気污染による健康障害」である.「農産物 への有害物質の蓄積」については，かりに玄米中に Cd が濃縮されて人体になんらかの障害を生じる（玄米の商 品価值もなくなる）影響を評価することにして，その単 位変化量を “玄米中 $\mathrm{Cd}$ 濃度 $1 \mathrm{ppm}$ ”設定する。一 方，「大気污染による健康障害」については，かりに空 気中の $\mathrm{SO}_{2}$ によって人体 (呼吸器) に慢性的障害が現 われる影響を評価することにして，その単位変化量を “ $\mathrm{SO}_{2}$ の空気中濃度 $0.02 \mathrm{ppm}$ ( 1 時間值の 1 日平均值)” と設定する. この例では $b_{2,8}=0.4$ であるから，ごみの 埋立が原因で玄米を摂取することにより生ずる健康障害 は $1 \mathrm{ppm}$ の Cd 米を食べる場合の障害の約 $40 \%$ であ ることになる，つまり，この場合，摂取すると推定され ている玄米中の $\mathrm{Cd}$ 濃度は $1 \mathrm{ppm} \times 0.4=0.4 \mathrm{ppm}$ （単 位変化量 $\times$ 変化指数) である. 同様に $b_{10,4}=0.8$ であ るから廃棄物の焼却が原因となって大気污染による健康 障害をうける程度は, $\mathrm{SO}_{2}$ による慢性的影響が顕在化す る場合の健康障害の約 $80 \%$ であることになる．影響の 単位変化量は，等しくなんらかの健康障害が出現する限 度量を参照して定められているのであるから， $b_{10,4}$ の影
響の方が $b_{2,8}$ の影響よりも大きいであろうと判定する ことになる。

このように環境影響の単位変化量をなんらかの身体的 障害が顕在化し始める限度に等しく設定すれば，当該事 業の実施によって生ずる環境影響が許容される限度以内 にあるか否かを容易に判断することもできる。すなわ ち, 行列 $\boldsymbol{B}$ の任意の行についてその行に属する全要素 を単純加算して得られる值が 1.0 を越えれば, 当該計画 案の棄却を検討することになる.

計画案の裹却基準 :

$$
\sum_{n=1}^{n} b_{j, n}>1 \quad(j=1,2, \cdots, n)
$$

i） 影響評価マトリックス $(\boldsymbol{A})$

式 (18) において,

$$
\boldsymbol{A} \equiv \boldsymbol{W} \cdot \boldsymbol{R} \cdot \boldsymbol{Q} \cdot \boldsymbol{P} \cdot \boldsymbol{M}
$$

とおくと式（18） は次式に書き改めることができる，A を影響評価マトリックスとよぶ.

$$
\boldsymbol{y}=\boldsymbol{A} \cdot \boldsymbol{i}
$$

行列 $\boldsymbol{A}$ は $l$ 行 $n$ 列の行列である. 行列 $\boldsymbol{B}$ と異な り, 行列 $\boldsymbol{A}$ では事業計画の実施によって生ずる影響を らける個人あるいは集団の当該環境影響に対する重要度 評価が加味されている. 行列 $\boldsymbol{A}$ の要素を $a_{j, n}$ とする と式 (27) に対応する式として次式を得る.

$$
y_{j}=\sum_{n=1}^{n} a_{j, n}(j=1,2, \cdots, l) .
$$

行列 $W$ は対角行列であるから, $a_{j, n}=w_{j, j} \cdot b_{j, n}$ で ある・

\begin{tabular}{|c|c|c|c|c|c|c|}
\hline 行 列 & 行列の名称 & 行列の 型 & 要 素 & 行列要素の意味とその決定方法 & $\begin{array}{l}\text { 決定に主に } \\
\text { 関与す吕者 }\end{array}$ & 行列の変化 \\
\hline $\boldsymbol{P}$ & $\begin{array}{l}\text { 開発行為一環 } \\
\text { 境要因マトリ } \\
\text { ックス }\end{array}$ & $\begin{array}{l}m \text { 行 } n \text { 列の } \\
\text { 実行列 }\end{array}$ & $p_{m, n}$ & $\begin{array}{l}\text { 第 } n \text { 開発行為が巣位規模 (規模指数 }=1.0 \text { ) のときの第 } \\
m \text { 環境要因の変化指数. 「開発行為一環境要因」直線の } \\
\text { 勾配. }\end{array}$ & $\begin{array}{l}\text { 研 究蒲 } \\
\text { 者 }\end{array}$ & \multirow{3}{*}{ 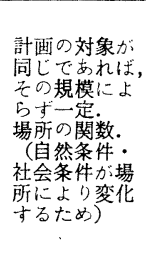 } \\
\hline $\boldsymbol{Q}$ & $\begin{array}{l}\text { 環境要母一環 } \\
\text { 境影響マトリ } \\
\text { ックス }\end{array}$ & $\begin{array}{l}l+\boldsymbol{k} \text { 行 } m \text { 列 } \\
\text { の実行列 }\end{array}$ & $\boldsymbol{q}_{j, m}$ & $\begin{array}{l}\text { 第 } m \text { 環境要因の変化が単位量 (変化指数 }=1.0) \text { の } \\
\text { き第 } j \text { 環境影響の変化指数. }(1 \leqq j \leqq l) \\
\text { 「環境要因一環境影警」直線の勾配. }\end{array}$ & 同上 & \\
\hline $\boldsymbol{R}$ & $\begin{array}{l}\text { 環境影響一環 } \\
\text { 境影響 }(\text { 相互) } \\
\text { マトリックス }\end{array}$ & $\begin{array}{l}l \text { 行 } l+k \text { 列 } \\
\text { の実行列 }\end{array}$ & $r_{l, j}$ & $\begin{array}{l}\text { 第 } j \text { 環境影響の変化が単位量 (变化指数 }=1.0) \text { のとき } \\
\text { の第 } l \text { 環境影響の変化指数. }(1 \leqq j \leqq l) \\
\text { 「環境影響—環境影響」直線の勾配. }\end{array}$ & 同上: & \\
\hline $\boldsymbol{W}$ & 重トリッグ 要 度 & 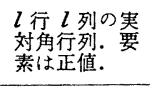 & $w_{j, j}$ & $\begin{array}{l}\text { 第 } j \text { 環境影響の相対的重要度. 各環境影響等が同程度 } \\
\text { である場合をべースにして決定する. }\end{array}$ & $\begin{array}{l}\text { 影響を弓ける } \\
\text { 個人・集団 } \\
\text { (住民) }\end{array}$ & $\begin{array}{l}\text { 個人・集団が } \\
\text { 同じであれば } \\
\text { 不変. }\end{array}$ \\
\hline $\boldsymbol{M}$ & 規 & $\begin{array}{l}n \text { 行 } n \text { 列の実 } \\
\text { 対角行列. 要 } \\
\text { 素は正値. }\end{array}$ & $m_{j, j}$ & $\begin{array}{l}\text { 第 } j \text { 開発行為の規模指数. }(1 \leqq j \leqq n) \\
\text { (規模指数 })=(\text { 開発行為の規模 }) /(\text { 笚位規模 })\end{array}$ & 計画立案者 & $\begin{array}{l}\text { 事業計画の質 } \\
\text { と規模により } \\
\text { 変化. }\end{array}$ \\
\hline $\boldsymbol{B}$ & $\begin{array}{l}\text { 環 境 影 響 } \\
\text { マトリックス }\end{array}$ & $\begin{array}{l}l \text { 行 } n \text { 列の実 } \\
\text { 行列 }\end{array}$ & $b_{j, n}$ & $\begin{array}{l}\text { 第 } n \text { 開発行為のみが原因 となり， } m \text { 個の環境要因， } \\
l \text { 個の環境影を媒介として生ずる第 } j \text { 環境影響の変化 } \\
\text { 指数. } \boldsymbol{B} \equiv \boldsymbol{R} \cdot \boldsymbol{Q} \cdot \boldsymbol{P} \cdot \boldsymbol{M}\end{array}$ & & \\
\hline $\boldsymbol{A}$ & $\begin{array}{l}\text { 環 境 評 価 } \\
\text { マトリックス }\end{array}$ & $\begin{array}{l}l \text { 行 } n \text { 列の実 } \\
\text { 行列 }\end{array}$ & $a_{j, n}$ & 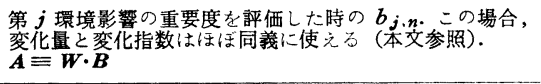 & & \\
\hline
\end{tabular}

式 (33) は， $n$ 個の開発行為が原因となり種々の環境 要因・影響を媒介として生ずる重要度を評価した第 $j$ 環 境影響の変化指数が, 行列 $\boldsymbol{A}$ の行列要素の和で与えら 表一4 行列の性質一覧

(注) $n:$ 開発行為の数, $m:$ 環境要因の数, $k: 2$ 次的に变化する環境要因の数 $(0 \leqq k \leqq m), l:$ 環境影響の数 
れることを示している．重要度を評価した後では “変化指数” は単位変化量を尺度にして 測定され た影響の程度を表わす指数として厳密な意味を損 ならから，それを“変化量”とよびかえてもよい． ただし，この “変化量”が依然として無次元量で あることには変わりがない， $a_{j, n}$ は第 $n$ 番目の 開発行為のみが原因となって生ずる, 重要度を評 価した第 $j$ 環境影響の变化指数 (変化量) を与 える..また, 行列 $\boldsymbol{A}$ の第 $n$ 列要素の単純和 $\sum_{j=1}^{l} a_{j, n}$ は第 $n$ 番目の開発行為のみが原因となっ て生ずる, 重要度を評価した $l$ 個の環境影響の変 化指数（変化量）の和を与える. それゆえ, 行列 $\boldsymbol{A}$ の要素の総和 $\sum_{j=1}^{l} \sum_{n=1}^{n} a_{j, n}$ は当該事業計画によ って生ずる, 重要度を評価した全環境影響の変化 量を与えることになる.

環境影響評価に用いる各行列の性質を整理して 表一4 に示寸. 表一 4 の第 5 欄には行列の作成に 関し，現状で考えられる役割分担を示した. 行列 $\boldsymbol{P}, \boldsymbol{Q}, \boldsymbol{R}$ は主として研究者・技術者が研究成果や 調査結果を活用して作成し, 行列 $\boldsymbol{W}$ 流影響をう ける個人または集団の意見によって作成し，ま た, 行列 $\boldsymbol{M}$ は計画立案者が作成するのが妥当で あろう・ただし，影響をうける個人または集団の 意見は当該事業計画の実施によって史跡その他に 回復不可能な悪影響が出る可能性がある場合に, 計画案の可否を判断する場合にも配虑される必要 がある (図一1 参照)。表一4 の第 6 欄には行列 およびその要素がどのような場合に変わるかを略 記した. 人の価値観や自然環境の生態学的特性, あるい は社会的諸条件等はすべて時間とともに変化する. これ らの行列 (の要素) が時間を媒介变数として持つことは 自明である。

\section{4. 評価手法の適用手順}

環境影響の評価手法の適用手順と必要な調查・資料・ 情報を整理して図一9に示す. 図一9 は図一1で示した 環境アセスメントの手続きのうち，環境影響評価の部分 をより詳しく図示している.

\section{5. 評価方法の特色}

本環境影響評価手法の特色を整理すると次のようにな る.

（1）環境変化の因果関係を行列で表示し，最終的に 問題になる環境影響がそれらの行列の積で与えられるこ との数学的背景を明らかにした．行列の積の形で環境影

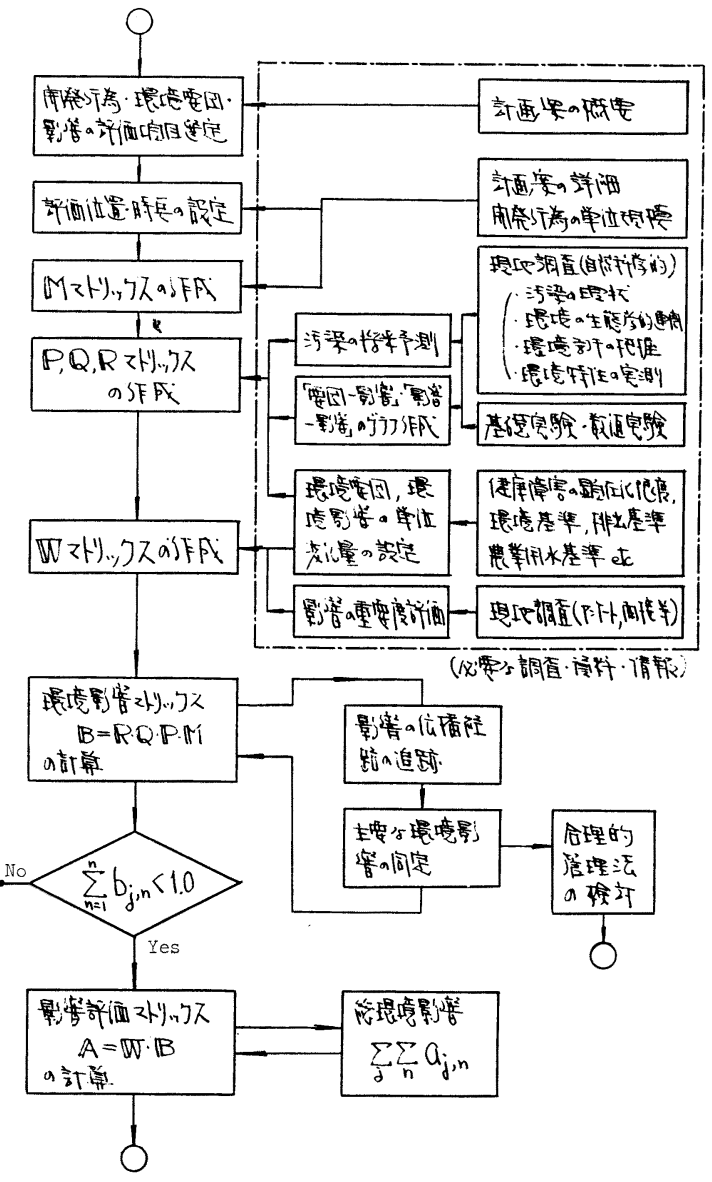

図一9環境影響評価手法の適用手順

（図一1 の当該部分を詳しく表示したもの）

響を評価する方法では，本法で示したような数学的基礎 が想定されていることになる。

（2）各行列の要素がもつ意味を明確にし，要素に与 える数值の定め方を明らかにした．単位規模, 単位変化 量を用いて行列の要素を無次元化することにより, 要素 の数值を相互に比較できるようにした，単位規模，単位 変化量の設定についても，その考え方を示した.

（3）本法で示した環境影響の評価手法は線形評価手 法である. 各行列, たとえば行列 $\boldsymbol{P}$ の要素 $p_{m, n}$ は環 境要因の変化原単位としての物理的意味を有していると 同時に, 数学的には第 $n$ 開発行為の変化に対する第 $m$ 環 境要因の変化の感度 (Sensitivity) でもある. 行列 $\boldsymbol{P}$, $\boldsymbol{Q}, \boldsymbol{R}$ に扔いて，各要素を比較することはそれぞれ対応 する感度を比較することにも相当する。

（4）評価手法を構成する 5 つの行列の性格を明らか にした（表一4 参照). 行列 $P, Q, R$ は主として研究 者・技術者によって作成され，当該事業計画の規模によ っては変化しない，行列 $W$ は主として環境影響をうけ る者によって決定される. また, 行列 $\boldsymbol{M}$ 法計画立案者 
によって決定され，事業計画の規模によってのみ変化す る. それゆえ, 開発行為の規模のみを変更する代替案に ついて環境影響を評価する場合には，規模マトリックス Mのみを変えるだけでよいことになる，これは線形評 価手法であることに由来する特色である.

（5）環境影響が許容限度を越えるとの理由で当該計 画案を棄却する基準を統一的に示した.

（6）そのほか，環境変化の因果関係を追跡すること ができるなど，ネットワーク法あるいは環境システムマ トリックス法がもつ特色をあわせて有している.

一方, 本手法の問題点としては次の諸項目があげられ る.

（1）本手法が 線形評価手法であることに付随して 種々の問題が生ずる.たとえば, 環境影響の相剰効果や 複合影響を評価する準備がされていない。これらの影響 は本評価手法では主として行列 $\boldsymbol{W}$ の要素值に包括され て評価されることになる．また，環境要因の変化あるい は環境影響の 変化が 本来的に 線形表示になじまない場 合，たとえば騒音のように音の強さ・大きさが音エネル ギーに比例しない場合には, 線形評価法は手法として本 来的な問題点を有していることになる.

（2）本手法に特有の問題点ではないが，本手法を現 実に適用する場合には現象の平均值に注目した評価手法 になる．実際には，たとえば開発行為（廃棄物の焼却） による環境要因（大気の污染）の変化は平均值の周囲に ある幅をもつ統計的変動量であると思われる.できる限 り多くの環境影響を総括的に評価し, かつ当該計画案を 実施したときに生ずる主要な影響がどこに現われるかを 予測しようとする環境アセスメントにおいて，環境影響 評価手法がどの程度の評価精度を持つべきかという問題 ともあわせて, 今後検討を要する問題である.

（3）環境影響マトリックス $\boldsymbol{B}$ および環境評価マト リックス $\boldsymbol{A}$ の各要素が相対的に比較できる量であるこ とは，それらがおのおの同程度の影響をもたらす単位量 によって無次元化されていることにより保証されてい る. 現実には，たとえば表一3に示した各環境影響が同 程度になるような各環境影響の変化量を定めるのは困難 な場合が多い. 疫学データ, 医学データ等を収集・整理 する必要がある。

\section{6. おわりに}

行列を用いて 環境の 変化を 表示する試みはレオポル
ド3)以来広く用いられており，その手法も，環境変化の 因果関係の 構造までも考慮すること等にみられるよう に, 次第に精密の度合を深めている. 行列法によって環 境影響を評価しようとする試みを批判して，考えられる 環境のすべてについて精密な影響評価をする立場が対圆 されることがあるが，これは行列法の枠内で個々の環境 影響の評価精度をむやみに向上させようとする意困に対 する批判であると思われる. 自然科学的な尺度で定量化 しにくい影響をも含めて，考えられる多くの項目につい ての影響を行列法等の手法で総括的に評価し，主要な影 響が何であり，どこに現われるか，また，それがどの開 発行為によってもたらされるのかを把握した後, それら の影響や行為ごとにさらに詳しい個別評価を行うべきで あろう. 最適計画案の選定後に実施する個別の詳細評価 は，施設の合理的管理法や有効な環境モニタリング法を 立案するうえでも不可欠である.

本評価手法をも含め多くの環境影響評価手法では，中 村らも指摘した 2 ように，“影響の時間的な長さ”をどの ように評価すべきかが明らかにされていない，続報で具 体的に明らかにするように，廃棄物の焼却・埋立処分場 で問題になる環境影響の発生時期およびその継続期間は 大きく異なる．たとえば，廃棄物の焼却による大気污染 の影響は廃棄物の焼却と同時に出現し，焼却の終了と同 時に終了する，ところが，焼却灰を埋立することによっ て生ずる地下水污染の影響は焼却灰の埋立後数年〜数十 年を経て初めて出現し長期間継続する。それゆえ，ある 時間断面における環境影響の程度やその大きさ（影響の 空間積分値）だけで当該計画の環境影響を比較するだけ では不十分である．生ずる影響の時間積分值等をも評価 指標に加える必要があると思われる.

最後に, 本評価手法の検討に際し土木計画学的立場か ら有益な助言をくださった京都大学工学部交通土木工学 教室の若井郁次郎助手に感謝の意を表します.

\section{参 考 文 献}

1）日本環境科学研究所：熊本港建設に伴う環境保全調查報 告書, 1975.

2）中村英夫ほか：システム・マトリックスに上る環境ア七 スメント，土木学会論文報告集 No. 248 , pp. 111 120, 1976 .

3) Luna B., Leopold et al. : A Procedure for Evaluat. ing Environmental Impact, Geological Survey Circular 645, Goverment Printing Office, U.S.A., 1971.

(1977.2.16 • 受付) 